\title{
PEMODELAN SISTEM PENDUKUNG KEPUTUSAN PENENTUAN SISWA TERBAIK MENGGUNAKAN METODE SIMPLE ADDICTIVE WEIGHTING (SAW)
}

\author{
Sri Melati ${ }^{1}$, Gandung Triyono ${ }^{2)}$ \\ Ilmu Komputer, Fakultas Teknologi Informasi, Universitas Budi Luhur \\ Jl. Raya Ciledug, Petukangan Utara, Kebayoran Lama, Jakarta Selatan 12260 \\ E-mail : riri.budiluhur@gmail.com ${ }^{1)}$, gandung.triyono@budiluhur.ac.id ${ }^{2)}$
}

\begin{abstract}
Abstrak
Siswa terbaik merupakan siswa berprestasi dan berakhlak mulia. Penilaian siswa terbaik dalam sebuah sekolah sangat penting untuk memotivasi para siswa dan siswi menjadi lebih baik. SDN Sungai Miai 5 Banjarmasin merupakan sekolah yang berencana menerapkan sistem penilaian siswa terbaik. Penetapan sistem penilaian siswa terbaik di SDN Sungai Miai 5 Banjarmasin dilakukan dengan menggabungkan kriteria dari program penilaian dibidang akademik dan nonakademik. Namun, dalam penggabungan kriteria pihak sekolah mengalami kesulitan, karena nilai kinerja yang digunakan mempunyai bentuk nilai yang berbeda, yaitu nilai kriteria dalam bentuk angka dan huruf. Sistem Pendukung Keputusan mampu memberikan solusi pemecahan masalah. Metode SAW (Simple Addictive Weighting) merupakan salah satu metode dalam sistem pendukung keputusan. Namun penerapan metode SAW perlu dipahami dengan baik oleh pengambil keputusan, terutama dalam menentukan bobot preferensi. Bobot preferensi dalam metode SAW mutlak ditentukan oleh orang pembuat keputusan. Hasil dari pengujian tiga skenario pembobotan dalam penelitian ini yaitu pengujian pengujian User Acceptance Testing (UAT) membuktikan bahwa bobot preferensi yang berbeda akan menghasilkan tingkat rangking yang berbeda. Hasil dari model yang dibangun menggunakan metode Simple Addictive Weighting (SAW) untuk menentukan siswa terbaik, dengan 6 kriteria kedisiplinan, akhlak, nilai raport, absensi, ektrakurikuler dan lomba, dapat memberikan hasil penentuan siswa terbaik yang efektif sesuai dengan pengujian model UAT dengan skor 31.73 atau 79,33\% dari 8 responden.
\end{abstract}

Kata Kunci: Sistem Pendukung Keputusan, Simple Addictive Weighting, Siswa Terbaik, UAT

\section{PENDAHULUAN}

Penghargaan kepada siswa dan siswi terbaik merupakan salah satu strategi pendidikan dalam memotivasi siswa - siswi untuk terus berprestasi dibidang akademik maupun non akademik pada tingkat Kota, provinsi bahkan nasional. Dalam proses menentukan siswa - siswi berprestasi diperlukan sistem pendukung keputusan yang dapat membantu guru dalam proses pemilihan siswa dan siswi terbaik yang sesuai kriteria secara objektif.

Dalam menentukan penilaian siswa berprestasi pada kurikulum 2013, melibatkan beberapa kriteria yang harus diambil karena ada tiga ranah kompetensi yang dinilai yaitu kompetensi sikap, kompetensi pengetahuan, dan kompetensi keterampilan. Didalam kompetensi sikap memiliki 4 jenis penilaian yaitu penilaian diri, penilaian antar teman, observasi dan jurnal. Didalam kompetensi keterampilan memiliki 3 jenis penilaian yaitu penilaian praktek, portofolio dan proyek. Dan pada kompetensi pengetahuan memiliki beberapa kompetensi inti yang harus dinilai. Dalam menentukan siswa berprestasi pada kurikulum 2013 menggunakan pengambilan rata-rata dari semua total nilai, baik nilai pengetahuan, keterampilan, maupun sikap yang kemudian diambil nilai rata-rata tertinggi dari semua siswa. Cara ini memiliki kelemahan yaitu tidak bisa memilih kriteria yang diutamakan untuk bisa menjadi acuan penentuan siswa berprestasi [1].

Dalam rangka memotivasi siswa - siswi untuk terus berprestasi sekolah melakukan kegiatan untuk mengembangkan potensi para siswa melalui pemilihan siswa teladan. Namun, pengambilan keputusan untuk memilih siswa teladan bukan atas kemampuan akademik dan non akademik, melainkan atas dasar subjektifitas kepala sekolah dan para guru terkait yang berbeda-beda. Sehingga banyak yang mengajukan komplain tentang keputusan terpilihnya siswa teladan yang kurang tepat sasaran. Penerapan metode SAW dalam penetuan siswa teladan berhasil diterapkan, sehingga diperoleh hasil sebagai suatu solusi untuk mendukung pengambilan keputusan dalam penentuan siswa teladan [2]. SDN Sungai Miai 5 merupakan sekolah dasar negeri yang terletak di Banjarmasin Utara. Jumlah siswa sebanyak 405 anak, yang terbagi menjadi 12 kelas.

Sebagai wujud bentuk partisipasi dalam mendidik siswa menjadi generasi unggulan, Pihak sekolah mempunyai program tahunan. Program yang diterapkan adalah pemilihan siswa terbaik. Siswa terbaik merupakan siswa berprestasi dan berakhlak mulia. Penilaian siswa terbaik dalam sebuah sekolah sangat penting untuk memotivasi para siswa menjadi lebih baik. SDN Sungai Miai 5 merupakan sekolah yang berencana menerapkan sistem penilaian siswa terbaik. Proses pemilihan penentuan siswa dan siswi terbaik di SDN Sungai Miai 5 Banjarmasin dilakukan dengan cara menggabungkan kriteria dari program penilaian siswa berprestasi akademik dan nonakademik, yaitu: Kedisiplinan, Akhlak, Nilai Raport, Absensi, Ekstrakulikuler dan Lomba yang masih dilakukan dengan cara perangkingan secara manual yang sangat rentan timbulnya penilaian 
yang subjektif, sehingga perlu dirancang sistem pengambil keputusan siswa dan siswi terbaik.

Namun dalam penggabungan nilai kriteria pihak sekolah mengalami kesulitan, karena nilai kriteria yang digunakan mempunyai bentuk nilai yang berbeda, yaitu nilai kriteria dalam bentuk angka dan huruf. Penggabungan nilai dalam bentuk yang berbeda perlu dibuat suatu pembobotan untuk membuat standar nilai dari setiap kriteria. Sistem pendukung keputusan mampu memeberikan solusi pemecahan masalah. Metode SAW merupakan salah satu metode yang digunakan dalam sistem pendukung keputusan. Penerapan metode SAW perlu dipahami dengan baik oleh pengambil keputusan, terutama dalam menentukan bobot preferensi. Bobot preferensi dalam metode SAW mutlak ditentukan oleh orang yang mengambil keputusan. Dalam menentukan bobot preferensi harus menggunakan pertimbangan yang tepat sesuai dengan tingkat kepentingan kriteria yang digunakan. Penentuan bobot preferensi yang tidak tepat akan menghasilkan keputusan yang salah.

Pada penelitan yang dilakukan oleh [1] merancang sistem pendukung keputusan siswa berbasis web pada SMK Negeri 1 Gedangan dengan menggunakan metode SAW dalam proses penentuan siswa berprestasi dimana hasil yang dihasilkan yaitu penilaian siswa berprestasi berdasarkan pada penilaian pada standard kurikulum 2013 yang melibatkan 3 ranah kompetensi peniliaian dalam pengambilan keputusan diantaranya kompetensi sikap, kompetensi nilai dan kompetensi keterampilan.

Pada penelitian lainnya yang dilakukan [2] merancang sistem pendukung keputusan untuk pemilihan siswa teladan menggunakan metode SAW di SMP Negeri Tasikmalaya dimana hasil yang dihasilkan dimana penentuan siswa berprestasi berdasar pada 9 kriteria yaitu rata - rata raport 2 semester akhir, peringkat kelas, absensi, keaktifan dalam berorganisasi, jabatan dalam organisasi, keikutsertaan perlombaan, kedisiplinan, akhlak dan akumulasi point pelanggaran.

Berdasarkan permasalahan dan penelitian terdahulu, pada penelitian ini akan menggunakan metode SAW dalam sistem pendukung keputusan dengan menggunakan beberapa kriteria diantaranya: Kedisiplinan, Akhlak, Nilai raport, absensi, Ekstrakulikuler dan lomba. Tujuan pada penelitian ini adalah Untuk mengetahui pengaruh Sistem Pendukung Keputusan terhadap penentuan Siswa terbaik di SDN Sungai Miai 5 Banjarmasin. Manfaat pada penelitian ini diantaranya Mengetahui pengaruh sistem pendukung keputusan terhadap penentuan siswa terbak di SDN Sungai Miai 5 Banjarmasin. Memudahkan dalam penentuan siswa terbaik di SDN Sungai Miai 5 Banjarmasin.

\section{METODE}

Keputusan merupakan hasil pemecahan dalam suatu masalah yang dihadapi dengan tegas. Menurut (Dagun, 2006) pengambilan keputusan didefinisikan sebagai pemilihan keputusan atau kebijakan yang didasarkan atas kriteria tertentu. Proses ini meliputi dua alternatif atau lebih karena seandainya hanya terdapat satu alternatif saja maka tidak ada satu keputusan yang diambil. Pengambilan keputusan menurut [3] dapat dianggap sebagai suatu hasil atau keluaran dari proses mental atau kognitif yang membawa pada pemilihan suatu jalur tindakan diantara beberapa alternatif yang tersedia. Setiap proses pengambilan keputusan selalu menghasilkan satu pilihan final. Dalam menentukan pilihan alternatif dapat menggunakan metode pembobotan, salahsatunya adalah metode SAW.

Metode SAW sering juga dikenal dengan istilah penjumlahan terbobot. Menurut [4] Konsep dasar metode SAW adalah mencari penjumlahan terbobot dari rating kinerja pada setiap alternative dari semua atribut, metode SAW membutuhkan proses normalisasi matrix keputusan (x) ke skala yang dapat diperbandingkan dengan semua rating alternatif yang ada.

$R_{i j}= \begin{cases}\frac{x_{i j}}{\max x_{i j}}, & \text { jika j adalah atribut keuntungan (benefit) } \\ \frac{\min x_{i j}}{x_{i j}}, & \text { jika j adalah atribut biaya (cost) }\end{cases}$

Dimana:

$R_{i j}=$ Rating Kinerja Ternormalisasi

$\max x_{i j=N i l a i}$ Maximum dari setiap baris dan kolom

$\min x_{i j}=$ Nilai Minimum dari setiap baris dan kolom

$x_{i j}=$ Baris dan kolom dari matriks

Menurut [4] Metode SAW disarankan untuk menyelesaikan masalah penyeleksian dalam sistem pengambilan keputusan multi proses. Metode SAW merupakan metode yang banyak digunakan dalam pengambilan keputusan yang memiliki banyak atribut. Ada beberapa langkah dalam penyelesaian metode SAW diantaranya:

1. Menentukan kriteria - kriteria yang dijadikan acuan dalam pendukung keputusan yaitu $C_{i}$.

2. Menentukan rating kecocokan setiap alternatif pada setiap kriteria.

3. Membuat matriks keputusan berdasarkan kriteria $\left(C_{i}\right)$.

4. Melakukan normalisasi matriks berdasarkan perasamaan yang disesuaikan dengan jenis atribut (atribut keuntungan maupun atribut biaya) sehingga diperoleh nilai matriks ternormalisasi $\mathrm{R}$.

5. Hasil akhir diperoleh dari proses perangkingan yaitu penjumlahan dari perkalian ternomalisasi $\mathrm{R}$ dengan vector bobot sehingga diperoleh nilai

Dengan Rạdalah rating kinerja ternormalisasi dari alternatif $A_{i}$ pada atribut $C_{j} ; \mathrm{i}=1,2,3, \ldots, \mathrm{m}$ dan $\mathrm{j}=1,2,3, \ldots, n$. Nilai preferensi untuk setiap alternative $\left(v_{i}\right)$ diberikan sebagai berikut :

Dimana:

$$
v_{i}=\sum_{j=1}^{n} w_{j} r_{i j}
$$

$v_{i}=$ Nilai akhir dari alternative

$w_{j}=$ Bobot yang telah ditentukan

$r_{i j}=$ Normalisasi Matriks 
Nilai vyang lebih besar mengindikasikan bahwa alternatif $A_{i}$ lebih terpilih.

Selain itu, menurut [4] metode SAW memiliki kelebihan dan kekurangan, yaitu :

1. Kelebihan metode SAW

a. Menentukan nilai bobot untuk setiap atribut, kemudian dilanjutkan dengan proses perangkingan untuk menyeleksi alternatif terbaik dari sejumlah alternatif.

b. Penilaian lebih mudah, karena kriteria dari nilai bobot preferensi sudah ditentukan.

c. Perhitungan normalisasi matriks sesuai dengan nilai atribut (antara nilai benefit dan cost).

2. Kekurangan Metode SAW

a. Digunakan untuk pembobotan lokal

b. Perhitungan yang dilakukan menggunakan bilangan crips dan fuzzy.

\section{ANALISA KEBUTUHAN MODEL}

Dalam dunia pendidikan, ada beberapa hal yang sangat ditekankan berkaitan dengan menjadi seorang siswa terbaik. Bukan hanya aspek akademik saja, tetapi dari segi kepribadian juga. Keseimbangan kedua aspek tersebut sangatlah diperlukan oleh setiap siswa. Agar nantinya dapat menjadi insan yang berguna bagi bangsa dan negara. Dan memiliki akhlak yang baik sehingga tidak hanya pintar, juga berbudi luhur.

Siswa Terbaik merupakan siswa yang mempunyai prestasi dan nilai yang paling baik dari siswa-siswa yang mempunyai nilai dan prestasi yang baik. Berdasarkan hasil analisa di lapangan yaitu di SDN Sungai Miai 5 Banjarmasin, penelitia ini mendapatkan 6 (enam) kriteria yang menjadi acuan dalam pengambilan keputusan untuk menentuan siswa terbaik. Kriteria-kriteria yang didapatkan adalah Kedisiplinan, Akhlak, Nilai Raport, Absensi, Nilai Ekstrakulikuler dan keikutsertaan lomba. Kriteria yang digunakan untuk menentukan siswa berprestasi dapat dilihat pada Tabel 1, di bawah ini.

\begin{tabular}{|c|c|c|c|}
\multicolumn{5}{c}{ Tabel 1. Tabel Pemilihan Kriteria } \\
\hline $\begin{array}{c}\text { Kode } \\
\text { Kriteria }\end{array}$ & $\begin{array}{c}\text { Ketentuan } \\
\text { Kriteria }\end{array}$ & $\begin{array}{c}\text { Bobot } \\
(\%)\end{array}$ & Keterangan \\
\hline C1 & Kedisiplinan & 20 & Cost \\
\hline C2 & Akhlak & 20 & Benefit \\
\hline C3 & Nilai Raport & 25 & Benefit \\
\hline C4 & Absensi & 10 & Cost \\
\hline C5 & Ekstrakulikuler & 10 & Benefit \\
\hline C6 & Lomba & 15 & Benefit \\
\hline
\end{tabular}

Nilai bobot kriteria dari Tabel 1 didapatkan dari pakar dilapangan (kepala sekolah), penjelasan setiap kriteria dapat dibaca pada keterangan sebagai berikut:

1. Kedisiplinan adalah sikap mental yang tercermin dalam perbuatan tingkah laku berupa kepatuhan atau ketaatan terhadap peraturan, ketentuan, etika, norma dan kaidah yang berlaku. Nialai dari kriteria ini adalah jumlah poin pelanggaran.

2. Akhlak adalah tingkah laku siswa yang didorong oleh suatu keingian secara sadar untuk melakukan suatu perbuatan yang baik. Nilai dari kriteria ini baru dapat diberikan dalam bentuk "Baik" atau "Tidak Baik"

3. Nilai Raport adalah nilai rata-rata dari semua mata pelajaran setiap semester. Nilai rata-rata dari raport ini adalah antara 0 sampai dengan 100 .

4. Absensi adalah nilai kehadiran dari setiap siswa yang berisi jam datang dan jam pulang serta alasan atau keteragangan kehadirannya. Nilai yang digunakan untuk pembobotan untuk nilai absensi adalah jumlah tidak hadir pada setiap semesternya.

5. Nilai Ekstrakulikuler adalah kegiatan non-pelajaran formal yang dilakukan peserta didik sekolah, umumnya di luar jam belajar, penilaian yang digunakan untuk pembobotan pada kiteria ini adalah jumlah kegiatan yang diikuti setiap mahasiswa.

6. Lomba adalah keikutsertaat setiap mahasiswa dalam keterampilan baik berupa ketangkasan, keterampilan di berbagai bidang pelajaran formal maupun nonformal. Penilaian dari lomba ini adalah jumlah keikutsertaan dalam mengikuti kegiatan dan seberapa besar peringkat yang diraih.

\section{Nilai Kriteria Kedisiplinan}

Kriteria kedisiplinan (C1) ini termasuk ke dalam nilai untuk menentukan siswa terbaik. Kriteria kedisiplinan merupakan nilai sikap siswa selama berada dalam lingkungan sekolah. Kedisiplinan ini juga nilai sikap mental yang tercermin dalam perbuatan tingkah laku berupa kepatuhan atau ketaatan terhadap peraturan, ketentuan, etika, norma dan kaidah yang berlaku. Dalam penilaian kedisiplinan ini adalah jumlah pelanggaran yang dilakukan oleh siswa, semakin sedikit siswa mendapat pelanggaran maka semakin bagus juga dalam penentuan siswa terbaik. Nilai akan di kategorikan tidak disiplin jika melakukan pelanggaran > 4, maka dapat dilihat pada Tabel 2.

Tabel 2. Tabel Nilai Kriteria Kedisiplinan

\begin{tabular}{|c|l|}
\hline $\begin{array}{c}\text { Jumlah } \\
\text { Pelanggaran }\end{array}$ & \multicolumn{1}{c|}{ Keterangan } \\
\hline 0 & Sangat Disiplin \\
\hline 1 & Disiplin \\
\hline 2 & Cukup Disiplin \\
\hline 3 & Kurang Disiplin \\
\hline$>=4$ & Tidak Disiplin \\
\hline
\end{tabular}

Dari Tabel 2 di atas terlihat semakin banyak pelanggaran maka semakin mempengarui tingkat kedisiplinan, sebaliknya semakin sedikit jumlah pelanggaran semakin bagus tingkat kedisiplinannya. Oleh sebab itu kriteria kedisiplinan ini pada penelitian ini dikategorikan kriteria cost.

Nilai kriteria kedisiplinan ini diperoleh berdasarkan hasil perilaku siswa terhadap pelanggaran-pelanggaran yang ada, semakin sedikit pelanggaran semakin bagus nilai siswa tersebut. 


\section{Nilai Kriteria Akhlak}

Kriteria akhlak (C2) ini termasuk ke dalam nilai untuk menentukan siswa terbaik. Kriteria akhlak merupakan tingkah laku siswa yang didorong oleh suatu keingian secara sadar untuk melakukan suatu perbuatan yang baik. Dalam penilaian akhlak ini adalah tingkah laku yang dilakukan oleh siswa, tingkah laku tersebut adalah baik dan tidak baik. Maka dapat dilihat kriteria akhlak pada Tabel 3

Tabel 3. Tabel Nilai Kriteria Akhlak

\begin{tabular}{|l|l|}
\hline Akhlak & Nilai Konversi \\
\hline Sangat Baik & 100 \\
\hline Baik & 80 \\
\hline Cukup Baik & 60 \\
\hline Tidak Baik & 1 \\
\hline
\end{tabular}

Dari Tabel 3 terlihat semakin baik tingkah laku siswa maka semakin baik nilai yang mempengarui tingkat akhlak. Oleh sebab itu kriteria akhlak pada penelitian ini dikategorikan kriteria benefit.

Penilaian kriteria akhlak berdasarkan keterangan, penilaian akhlak hanya 4 yaitu sangat baik, baik, cukup baik, dan tidak baik. Dalam penilaian dengan metode SAW nilai kriteria ini harus di konversi ke numerik agar dapat dilakukan proses perhitungan. Kriteria akhlak sangat baik menjadi nilai 100 , baik menjadi nilai 80 , cukup baik menjadi nilai 60 dan tidak baik menjadi nilai 1. Nilai tidak baik menjadi 1 karena jika dihitung sebagai pembagi maka tidak boleh 0 .

\section{Nilai Kriteria Nilai Raport}

Kriteria nilai raport (C3) ini termasuk ke dalam nilai untuk menentukan siswa terbaik. Kriteria nilai raport merupakan dari nilai rata-rata dari semua mata pelajaran siswa tiap semester. Dalam penilaian nilai raport ini nilai rata-rata semua pelajaran, rentang nilai pada kriteria ini adalah 0-100. Maka dapat dilihat kriteria nilai raport pada Tabel 4.

Tabel 4. Tabel Nilai Kriteria Nilai Raport

\begin{tabular}{|c|c|}
\hline Nilai Rata-Rata & Keterangan \\
\hline $90-100$ & Sangat Baik \\
\hline $80-89$ & Baik \\
\hline $70-79$ & Cukup Baik \\
\hline $60-69$ & Kurang Baik \\
\hline $30-49$ & Tidak Baik \\
\hline$<30$ & Sangat Tidak Baik \\
\hline
\end{tabular}

Dari Tabel 4 terlihat semakin tinggi nilai rata-rata dari raport siswa, maka semakin baik nilai bobot yang mempengarui nilai kriteria nilai raport. Pada nilai raport ini nilai bobot yang digunakan adalah nilai asli dari nilai raport tanpa konversi ke nilai bobot. Oleh sebab itu kriteria nilai raport pada penelitian ini dikategorikan kriteria benefit. Nilai raport ini tidak ada di lakukan konversi, karena nilai raport ini sudah numerik dan nilai raport lebih bagus jika nilai tersebut murni tidak ada perubahan nilai.

\section{Nilai Kriteria Absensi}

Kriteria absensi (C4) ini termasuk ke dalam nilai untuk menentukan siswa terbaik. Kriteria absensi merupakan daftar kehadiran siswa yang berisi jam datang dan jam pulang serta alasan atau keteragangan kehadirannya. Dalam penilaian kriteria absensi ini berdasarkan jumlah kehadiran siswa. Maka dapat dilihat kriteria nilai absensi pada Tabel 5.

Tabel 5. Tabel Nilai Kriteria Absensi

\begin{tabular}{|c|c|}
\hline Jumlah Absen & Keterangan \\
\hline 0 & Sangat Baik \\
\hline $1-3$ & Baik \\
\hline $4-8$ & Cukup Baik \\
\hline $9-15$ & Kurang Baik \\
\hline$>15$ & Sangat Tidak Baik \\
\hline
\end{tabular}

Dari Tabel 5 terlihat semakin banyak jumlah absen, maka semakin kecil nilai bobot yang mempengarui nilai kriteria absen. Begitu sebaliknya, semakin sedikit jumlah absen semakin bagus. Oleh sebab itu kriteria nilai raport pada penelitian ini dikategorikan kriteria cost. Nilai dari kritera absensi ini tidak ada konversi nilai sama halnya dengan nilai raport, tetapi nilai absensi ini semakin banyak nilai semakin jelek nilai kategorinya.

\section{Nilai Kriteria Ektrakurikuler}

Kriteria ektrakurikuler (C5) ini termasuk ke dalam nilai untuk menentukan siswa terbaik. Kriteria ekstrakurikuler ini merupakan kegiatan non-pelajaran formal yang dilakukan peserta didik sekolah, umumnya di luar jam belajar kurikulum standar. Dalam penilaian nilai ektrakurikuler ini adalah jumlah kegiatan yang diikuti oleh siswa. Maka dapat dilihat kriteria ektrakurikuler pada Tabel 6.

Tabel 6 Tabel Nilai Kriteria Ektrakurikuler

\begin{tabular}{|c|c|}
\hline $\begin{array}{c}\text { Jumlah } \\
\text { Kegiatan }\end{array}$ & Nilai Konversi \\
\hline$>=3$ & 100 \\
\hline 2 & 80 \\
\hline 1 & 60 \\
\hline 0 & 1 \\
\hline
\end{tabular}

Dari Tabel 6 terlihat semakin banyak mengikuti kegiatan ektrakurikuler, maka semakin baik nilai konversi yang mempengarui nilai kriteria ekstrakurikuler. Oleh sebab itu kriteria ektrakurikuler pada penelitian ini dikategorikan kriteria benefit.

Nilai dari kriteria ektrakurikuler ini numerik tapi juga dikonversi karena batasan ektrakurikuler hanya 3 kegiatan jadi jika banyak ektrakurikuler yang diikuti tidak berpengaruh karena cukup hanya 3 kegiatan nilai konversinya sudah 100 , sebaliknya jika 0 kegiatan maka akan dikonversi menjadi 1 .

\section{Nilai Kriteria Lomba}

Kriteria lomba (C6) ini termasuk ke dalam nilai untuk menentukan siswa terbaik. Kriteria lomba ini merupakan adu keterampilan baik berupa ketangkasan, keterampilan di berbagai bidang pelajaran formal maupun non-formal. Dalam penilaian nilai lomba ini 
adalah jumlah prestasi dari mengikuti lomba yang diikuti oleh siswa. Maka dapat dilihat kriteria ektrakurikuler pada Tabel 7 .

\begin{tabular}{|c|c|}
\hline Tabel 7 Tabel Nilai Kriteria Ektrakuriluler \\
\hline Lomba & Nilai Bobot \\
\hline Juara 1 & 100 \\
\hline Juara 2 & 80 \\
\hline Juara 3 & 60 \\
\hline Mengikuti Lomba & 40 \\
\hline $\begin{array}{c}\text { Tidak Pernah Mengikuti } \\
\text { Lomba }\end{array}$ & 1 \\
\hline
\end{tabular}

Dari Tabel 7 terlihat semakin bagus yang dihasilkan pada kegiatan lomba, maka semakin baik nilai bobot yang mempengarui nilai kriteria lomba. Oleh sebab itu kriteria lomba pada penelitian ini dikategorikan kriteria benefit.

Penilaian kriteria lomba berdasarkan keterangan, penilaian lomba hanya 5 yaitu juara 1 , juara 2, juara 3, mengikuti lomba dan tidak pernah mengikuti lomba. Dalam penilaian dengan metode SAW nilai kriteria ini harus di konversi ke numerik agar dapat dilakukan proses perhitungan. Nilai kriteria lomba untuk juara 1 menjadi 100, juara 2 menjadi 80 , juara 3 menjadi 60 , pernah mengikuti lomba menjadi 40 dan tidak pernah mengikuti lomba menjadi 1. Nilai tidak pernah mengikuti lomba menjadi 1 karena jika dihitung sebagai pembagi maka tidak boleh 0 .

\section{HASIL DAN PEMBAHASAN}

\subsection{Model SPK Penentuan Siswa Terbaik}

Model sistem pengambil keputusan yang dihasilkan diperlihatkan dalam use case model, lihat Gambar 1. Pada Gambar tersebut menunjukkan beberapa fungsi yang terdapat pada model SPK untuk pemilihan siswa terbaik.



Gambar 1. Model SPK Pemilihan Siswa Terbaik

Gambar 1, terdapat dua aktor yang terlibat pada sistem ini yaitu admin dan guru. Aktor Admin mempunyai hak akses terhadap beberapa fasilitas yaitu akses halaman user aplikasi, kriteria dan pembobotan, data siswa, proses perangkingan dan laporan. Sedangkan untuk Aktor Guru hanya bisa menginputkan akses untuk pendataan data siswa atau alternatif.

\subsection{Pembobotan dengan SAW}

Pada penelitian ini pertama membuat data awal nilai alternative semua siswa, nilai siswa pada tahap pertama ini adalah, nilai murni siswa tanpa konversi ke nilai bobot masing-masing kriteria, sebagai contoh perhitungan terlihat pada Tabel 8 , data awal yang akan dihitung:

\begin{tabular}{|c|c|c|c|c|c|c|}
\hline \multicolumn{7}{|c|}{ Tabel 8. Nilai Alternatif Siswa Terbaik } \\
\hline \multirow{2}{*}{ Alternatif } & \multicolumn{6}{|c|}{ Kriteria Siswa Terbaik } \\
\hline & $\mathrm{C} 1$ & $\mathrm{C} 2$ & $\mathrm{C} 3$ & $\mathrm{C} 4$ & $\mathrm{C} 5$ & C6 \\
\hline A1 & 3 & $\begin{array}{c}\text { Cukup } \\
\text { Baik }\end{array}$ & 90 & 1 & 3 & Juara 3 \\
\hline A2 & 1 & $\begin{array}{c}\text { Sangat } \\
\text { Baik }\end{array}$ & 70 & 2 & 1 & Peserta \\
\hline A3 & 1 & $\begin{array}{c}\text { Sangat } \\
\text { Baik }\end{array}$ & 80 & 4 & 1 & Juara 2 \\
\hline A4 & 1 & Baik & 75 & 3 & 2 & Peserta \\
\hline A5 & 2 & $\begin{array}{c}\text { Cukup } \\
\text { Baik }\end{array}$ & 85 & 2 & 3 & Juara 1 \\
\hline
\end{tabular}

Pada Tabel 8 adalah tabel nilai alternative siswa terbaik berdasarkan data awal, maka data tersebut akan di konversi ke nilai masing-masing kriteria, maka diperoleh hasil konversi nilai tersebut pada Tabel 9.

Tabel 9. Nilai Alternatif Siswa Terbaik Setelah Dikonversi

\begin{tabular}{|c|c|c|c|c|c|c|}
\hline \multirow{2}{*}{ Alternatif } & \multicolumn{7}{|c|}{ Kriteria Siswa Terbaik } \\
\cline { 2 - 7 } & C1 & C2 & C3 & C4 & C5 & C6 \\
\hline A1 & 3 & 60 & 90 & 1 & 100 & 60 \\
\hline A2 & 1 & 100 & 70 & 2 & 60 & 40 \\
\hline A3 & 1 & 100 & 80 & 4 & 60 & 80 \\
\hline A4 & 1 & 80 & 75 & 3 & 80 & 40 \\
\hline A5 & 2 & 60 & 85 & 2 & 100 & 100 \\
\hline Bobot $(w)$ & 0.20 & 0.20 & 0.25 & 0.10 & 0.10 & 0.15 \\
\hline
\end{tabular}

Tabel 9 adalah nilai alternative siswa terbaik yang sudah dikonversi dari data awal, sedangkan bobot (w) didapat dari Tabel 1. Setalah mendapatkan nilai alternative maka dapat di presentasikan ke dalam matriks berikut ini:

$$
x=\left\{\begin{array}{rccccc}
3 & 60 & 90 & 1 & 100 & 60 \\
1 & 100 & 70 & 2 & 60 & 40 \\
1 & 100 & 80 & 4 & 60 & 80 \\
1 & 80 & 75 & 3 & 80 & 40 \\
2 & 60 & 85 & 2 & 100 & 100
\end{array}\right.
$$

Setelah dijadikan matrik $x$, kemudian nilai matrik $x$ di normalisasikan dengan rumus:

$R_{i j}= \begin{cases}\frac{x_{i j}}{\max x_{i j}}, & \text { jika } j \text { adalah atribut keuntungan (benefit) } \\ \frac{\min x_{i j}}{x_{i j}}, & \text { jika } j \text { adalah atribut biaya (cost) }\end{cases}$ 
Maka perhitungannya adalah sebagai berikut:

$R 11=\frac{\min \{31112\}}{3}=\frac{1}{3}=\mathbf{0}, \mathbf{3 3}$

$R 12=\frac{60}{\max (601001008060)}=\frac{60}{100}=\mathbf{0 , 6 0}$

$R 13=\frac{90}{\max (9070807585)}=\frac{90}{90}=\mathbf{1 , 0}$

$R 14=\frac{\min (124432)}{1}=\frac{1}{1}=\mathbf{1}, \mathbf{0}$

$R 15=\frac{100}{\max (100606080100)}=\frac{100}{100}=\mathbf{1}, \mathbf{0}$

$R 16=\frac{60}{\max (60408040100)}=\frac{60}{100}=\mathbf{0 , 6}$

Kemudian setelah data alternative pertama dihitung dilanjutkan dengan perhitungan data alternative ke-2

$$
\begin{aligned}
& R 21=\frac{\min \{31112\}}{1}=\frac{1}{1}=\mathbf{1} \\
& R 22=\frac{100}{\max (601001008060)}=\frac{100}{100}=1,0 \\
& R 23=\frac{70}{\max (9070807585)}=\frac{70}{90}=\mathbf{0 , 7 8} \\
& R 24=\frac{\min (12432)}{2}=\frac{1}{2}=\mathbf{0 , 5} \\
& R 25=\frac{60}{\max (100606080100)}=\frac{60}{100}=\mathbf{0 , 6} \\
& R 26=\frac{40}{\max (60408040100)}=\frac{40}{100}=\mathbf{0 , 4}
\end{aligned}
$$

Kemudian setelah data alternative kedua dihitung dilanjutkan dengan perhitungan data alternative ke-3

$$
\begin{aligned}
& R 31=\frac{\min \{31112\}}{1}=\frac{1}{1}=\mathbf{1} \\
& R 32=\frac{100}{\max (601001008060)}=\frac{100}{100}=1, \mathbf{0} \\
& R 33=\frac{80}{\max (9070807585)}=\frac{80}{90}=\mathbf{0 , 8 8} \\
& R 34=\frac{\min (12432)}{4}=\frac{1}{4}=\mathbf{0 , 2 5} \\
& R 35=\frac{60}{\max (100606080100)}=\frac{60}{100}=0,6 \\
& R 36=\frac{80}{\max (60408040100)}=\frac{80}{100}=\mathbf{0 , 8}
\end{aligned}
$$

Kemudian setelah data alternative ketiga dihitung dilanjutkan dengan perhitungan data alternative ke-4

$$
\begin{aligned}
& R 41=\frac{\min \{31112\}}{1}=\frac{1}{1}=\mathbf{1} \\
& R 42=\frac{80}{\max (601001008060)}=\frac{80}{100}=\mathbf{0 , 8} \\
& R 43=\frac{75}{\max (9070807585)}=\frac{75}{90}=\mathbf{0 , 8 3} \\
& R 44=\frac{\min (12432)}{2}=\frac{1}{3}=\mathbf{0}, \mathbf{3 3} \\
& R 45=\frac{80}{\max (100606080100)}=\frac{80}{100}=\mathbf{0 , 8} \\
& R 46=\frac{40}{\max (60408040100)}=\frac{4}{100}=\mathbf{0 , 4}
\end{aligned}
$$

Kemudian setelah data alternative keempat dihitung dilanjutkan dengan perhitungan data alternative ke-5 (data terakhir dalam contoh ini).

$$
\begin{aligned}
& R 51=\frac{\min \{31112\}}{1}=\frac{1}{2}=\mathbf{0 , 5} \\
& R 52=\frac{60}{\max (601001008060)}=\frac{60}{100}=\mathbf{0 , 6} \\
& R 53=\frac{85}{\max (9070807585)}=\frac{85}{90}=\mathbf{0 , 9 4} \\
& R 54=\frac{\min (12432)}{2}=\frac{1}{2}=\mathbf{0}, \mathbf{5} \\
& R 55=\frac{100}{\max (100606080100)}=\frac{100}{100}=\mathbf{1 , 0} \\
& R 56=\frac{100}{\max (60408040100)}=\frac{1.0}{100}
\end{aligned}
$$

Setelah dilakukan semua perhitungan dari matrik $x$, maka diperoleh hasil matrik $r$ atau matrik $x$ ternormalisasi. Adapun hasil matrik dapat dilihat pada Tabel 10 dibawah ini.

Tabel 10 Hasil Normalisasi R

\begin{tabular}{|l|l|l|l|l|l|l|}
\hline \multirow{2}{*}{ Alternative } & \multicolumn{7}{|c|}{ Kriteria Siswa Terbaik } \\
\cline { 2 - 7 } & C1 & C2 & C3 & C4 & C5 & C6 \\
\hline A1 & 0,33 & 0,6 & 1,0 & 1,0 & 1,0 & 0,6 \\
\hline A2 & 1,0 & 1,0 & 0,78 & 0,5 & 0,6 & 0,4 \\
\hline A3 & 1,0 & 1,0 & 0,88 & 0,25 & 0,6 & 0,8 \\
\hline A4 & 1,0 & 0,8 & 0,83 & 0,33 & 0,8 & 0,4 \\
\hline A5 & 0,5 & 0,6 & 0,94 & 0,5 & 1,0 & 1,0 \\
\hline
\end{tabular}

Pada Tabel 10 adalah hasil dari normalisasi dari matrik $x$, hasil nilai alternatif ini akan diproses perangkingan yaitu penjumlahan dari perkalian normalisasi $R$ dengan vector bobot (bobot preference), sehingga diperoleh nilai terbesar yang dipilih sebagai alternative terbaik sebagai solusi.

Nilai bobot preference dalam penelitian ini adalah sebagai berikut:

$w=(0.20,0.20,0.25,0.10,0.10,0.15)$

Maka dihitung setiap alternatife dengan perkalian bobot pada setiap kriteria, perhitungannya adalah sebagai berikut:

$v 1=(0,20 \times 0,33)+(0,20 \times 0,6)+(0,25 \times 1,0)+(0,10 \times 1,0)+(0,10 \times 1,0)+(0,15 \times 0,6)$ $v 1=0,07+0,12+0,25+0,10+0,10+0,09=0,73$

Dilanjutkan menghitung nilai akhir alternative ke-2 $v 2=(0,20 \times 1,0)+(0,20 \times 1,0)+(0,25 \times 0,78)+(0,10 \times 0,5)+(0,10 \times 0,6)+(0,15 \times 0,4)$ $v 2=0,20+0,20+0,19+0,05+0,06+0,06=0,760$ Dilanjutkan menghitung nilai akhir alternative ke-3 $v 3=(0,20 \times 1,0)+(0,20 \times 1,0)+(0,25 \times 0,88)+(0,10 \times 0,25)+(0,10 \times 0,6)+(0,15 \times 0,8)$ $v 3=0,20+0,20+0,22+0,025+0,06+0,12=0,825$

Dilanjutkan menghitung nilai akhir alternative ke-4 $v 4=(0,20 \times 1,0)+(0,20 \times 0,8)+(0,25 \times 0,83)+(0,10 \times 0,33)+(0,10 \times 0,8)+(0,15 \times 0,4)$ $v 4=0,20+0,16+0,21+0,033+0,08+0,06=0,743$

Dilanjutkan menghitung nilai akhir alternative ke-5 $v 5=(0,20 \times 0,5)+(0,20 \times 0,6)+(0,25 \times 0,94)+(0,10 \times 0,5)+(0,10 \times 1,0)+(0,15 \times 1,0)$ $v 5=0,10+0,12+0,235+0,05+0,10+0,15=0,755$

Setelah dilakukan semua perhitungan alternative dengan perkalian bobot $w$ dengan data ternormalisasi, maka didapat alternatif nilai terbaik ada pada alternatif A3 yaitu dengan nilai $\mathbf{0 , 8 2 5}$. Adapun hasil perangkingan dari semua perhitungan dapat dilihat pada tabel

Tabel 11 Hasil Perhitungan bobot $\mathrm{W}$ dikali normalisasi R 


\begin{tabular}{|c|c|c|}
\hline Alternaif & Hasil & Ranking \\
\hline A1 & 0,730 & 5 \\
\hline A2 & 0,760 & 2 \\
\hline A3 & $\mathbf{0 , 8 2 5}$ & $\mathbf{1}$ \\
\hline A4 & 0,743 & 4 \\
\hline A5 & 0,755 & 3 \\
\hline Tabel 11 mempresentasikan hasil solusi
\end{tabular}
alternatif dengan metode SAW, alternatif A3 mendapat ranking 1 dengan hasil 0,825., kemudian $\mathrm{A} 2$ dengan hasil 0,760., A5 dengan hasil 0,755., A4 dengan hasil 0,743., dan ranking terakhir adalah A1 dengan hasil 0,730.

\subsection{Pengujian Model}

Dalam penelitian ini untuk pengujian model menggunakan pendekatan User Acceptance Testing (UAT). Model yang diuji berbentuk prototipe, pengujian bertujuan untuk mengetahui seberapa sesuai model yang dikembangkan dengan kebutuhan manajemen khususnya di SDN Sungai Miai 5 Banjarmasin. Pengujian menggunakan responden sebanyak 8 orang yang terdiri dari guru dan staff di SDN Sungai Miai 5 Banjarmasin.

Dalam pengujian menggunakan kuesioner. Kuesioner dibuat dalam limabelas pertanyaan, semua pertanyaan yang dibuat sudah disesuaikan dengan kebutuhan pengambilan keputusan dan dilakukan validasi. Dalam melakukan pengujian dibentuk kuesioner dengan mempertimbangkan beberapa topik, seperti kebutuhan penggunaan, kemudahan menggunakan aplikasi, kesesuaian kelengkapan data, dan keluaran hasil perangkingan yang dihasilkan.

Pengukuran kesesuaian dari model yang dikembangan menggunakan skala likert. Pada skala likert perhitungan prosentase kesesuaian model menggunakan skor ideal (kriterium), dengan perhitungan sebagai berikut:

Skor Kriterium=Bobot Nilai Skala Jawaban $\mathrm{x}$ Jumlah Responden

Skor kriterium merupakan skor tertinggi yang digunakan untuk mengitung skor dalam menentukan rating skala dan jumlah seluruh jawaban. Pada penelitian ini digunakan skala 1 sampai 5 untuk jawaban dan jumlah responden 8 , maka skor kriterium yang terbentuk dapat dilihat pada Tabel 12.

\begin{tabular}{|c|c|} 
Tabel 12 Skor Kriterium \\
\hline Rumus & Skala \\
\hline $5 \times 8=40$ & SS \\
\hline $4 \times 8=32$ & S \\
\hline $3 \times 8=24$ & CS \\
\hline $2 \times 8=16$ & TS \\
\hline $1 \times 8=8$ & STS \\
\hline
\end{tabular}

Pada Tabel 12, ditunjukan bahwa nilai skala yang diberikan untuk skor kriterium adalah Sangat Sesuai (SS), Sesuai (S), Cukup Sesuai (CS), Tidak Sesuai (TS), dan Sangat Tidak Sesuai (STS). Nilai skor tertinggi untuk $\mathrm{SS}=40, \mathrm{~S}=32, \mathrm{CS}=24, \mathrm{TS}=16$ dan $\mathrm{STS}=8$.

Selanjutnya semua jawaban responden dijumlahkan dan dimasukan kedalam rating skala dan ditentukan daerah jawabannya. Rating skala digunakan untuk mengetahui hasil data kuesioner secara umum dan keseluruhan jawaban yang didapatkan dari penilaian kuesioner. Skala rating yang terbentuk dapat dilihat pada Tabel 13.

Tabel 13 Skala Rating
\begin{tabular}{|c|c|}
\hline Nilai Jawaban & Skala \\
\hline $0-8$ & STS \\
\hline $9-16$ & TS \\
\hline $17-24$ & CS \\
\hline $25-32$ & S \\
\hline $33-40$ & SS \\
\hline
\end{tabular}

Tabel 13 adalah tabel skala rating, skala rating tertinggi atau sangat sesuai pada skala 33-40 dan skala terendah 0-8 untuk sangat tidak sesuai.

Hasil kuesioner yang telah diisi mendapatkan hasil rata-rata 31.73 (tiga satu koma tujuh puluh tiga) atau $79.33 \%$ dari 15 pertanyaan dan 8 responden. Jika rata-rata tersebut dimasukan dalam skala rating, maka mendapatkan penilaian $\mathbf{S}$ atau Sesuai. Secara detail nilai dari hasil kuesioner dapat dilihat pada paragraf berikutnya.

\section{KESIMPULAN}

Berdasarkan pembahasan hasil penelitian yang sudah dibahas maka dapat ditarik kesimpulan yaitu model yang dibangun menggunakan metode Simple Addictive Weighting (SAW) untuk menentukan siswa terbaik, dengan 6 kriteria kedisiplinan, akhlak, nilai raport, absensi, ektrakurikuler dan lomba, dapat memberikan hasil penentuan siswa terbaik yang sesuai dengan pengujian model UAT dengan skor skala 31.73 dalam prosentasi $79,33 \%$ dari 8 responden. Sistem pendukung keputusan penentuan siswa terbaik di SDN Sungai Miai 5 Banjarmasin ini masih dapat dikembangkan, adapun saran pengembangan sistem diantaranya menambahkan kriteria yang belum ada dalam penelitian ini, sehingga bisa lebih sepesifik lagi dalam penentuan siswa terbaik, melakukan pembobotan dengan metode lain dan membuat kriteria dinamis agar fleksibilitas dalam pembaharuan kriteria pada masa akan dating.

\section{DAFTAR PUSTAKA}

[1] Z. Abidin and Y. Ardian. (2013) 'Sistem Pendukung Keputusan Penilaian Siswa Berprestasi Kurikulum 2013 Berbasis Web Pada Smk Negeri 1 Gedangan Menggunakan Metode Saw'. doi: 10.1007/s10854-007-9147-2.

[2] E. Dewi. (2015) 'Teladan Menggunakan Metode Simple Additive ( Studi Kasus : Di Smp Negeri 3 Tasikmalaya )', Seminar Nasional Informatika, pp. 38-44.

[3] J. Reason (1990) 'Human Eror Managing', ashgate, ISBN 1-840.

[4] S. Kusumadewi dan Purnomo (2010) Aplikasi Logika Fuzzy untuk Pendukung Keputusan Edisi 2. yogyakarta: graha ilmu. 